\title{
Haemoglobin Genotypes, ABO Blood Groups, and Burkitt's Tumour
}

\author{
A. OLUFEMI WILLIAMS \\ From the Department of Pathology, University of Ibadan, Ibadan, Nigeria
}

The relation between genetic markers, such as blood groups and secretor status of patients and malignant neoplasms, has been investigated by several workers (Aird, Bentall, Mehigan, and Roberts, I954; Aird, Lee, and Roberts, 1960; Beasley, 1960; Hembold, 1959). There is some evidence that an association exists between certain blood groups and malignant neoplasms. However, haemoglobin which is another genetic marker, has very seldom been considered or studied in relation to malignant tumours. It was decided, therefore, to see if there was any relation between haemoglobin genotypes or blood groups and Burkitt's tumour-a relatively common but unusual malignant lymphoma syndrome of childhood encountered in tropical Africa (Burkitt, 1958).

\section{Subjects and Methods}

The data were obtained from the case records of 100 Nigerian children of Yoruba tribe who attended or were admitted to the University College Hospital, Ibadan, during a five-year period, 1960-1965. There were 60 boys and 40 girls between the ages of 5 and 15 years. All the patients had clinical and typical histological pictures of Burkitt's tumour. Other tumours of the reticuloendothelial system were excluded from the study. Blood grouping and haemoglobin electrophoresis were carried out. Post-mortem blood samples were not used.

In order to compare the results with suitable controls, it was necessary that patients and controls belonged to the Yoruba tribe, were resident in a comparable area, and were within the same age range. In fact the controls were children who attended hospital during the five-year period. The ABO blood group distribution was known for 636 children and 26,027 adult blood donors of similar tribe (Gilles, I963; see Table III). The haemoglobin genotype was also known for a number of Yoruba children (33I) of the same age, living in a comparable area (Table I).

Received October 5, 1965.

\section{Results}

Table I shows the haemoglobin electrophoretic distribution of the 100 patients with that expected from the $33 \mathrm{I}$ controls. There is a significant difference $\left(\chi^{2}=3.708 ; p<0 \cdot 10\right)$ between the observed and expected distributions. There is also a significant difference between 95 patients and 320 controls $\left(\chi^{2}=5.17 ; p<0.05\right)$, having excluded the groups with SS, CC, SC, AC (Table III). There is, however, no difference between the ABO distribution of the patients compared with that expected from the controls (Table III).

\section{TABLE I}

DISTRIBUTION OF IOO PATIENTS WITH BURKITT'S TUMOUR BY HAEMOGLOBIN ELECTROPHORESIS COMPARED WITH EXPECTED DISTRIBUTION FROM CONTROLS

\begin{tabular}{l|c|c}
\hline $\begin{array}{c}\text { Haemoglobin Genotype } \\
\text { (by paper electrophoresis) }\end{array}$ & $\begin{array}{c}\text { No. of } \\
\text { Patients }\end{array}$ & $\begin{array}{c}\text { No. of } \\
\text { Controls* }\end{array}$ \\
\hline AA SC, SS, CC, AC & 78 & 225 \\
AS, SC, & 22 & 106 \\
\hline Total & 100 & 331 \\
\hline
\end{tabular}

* Worlledge (1959). $\chi^{2}=3.708 ;$ d.f. $=1 ; p<0.10$.

TABLE II

DISTRIBUTION OF 95 PATIENTS WITH AA AND AS GENOTYPES COMPARED WITH EXPECTED DISTRIBUTION FROM CONTROLS

\begin{tabular}{l|c|c}
\hline \multicolumn{1}{c|}{ Haemoglobin Genotype } & No. of Patients & No. of Controls* \\
\hline AA & 78 & 225 \\
AS & 17 & 95 \\
\hline Total & 95 & 320 \\
\hline
\end{tabular}

$* \chi^{2}=5.17 ;$ d.f. $=1 ; p<0.05$.

Note: Patients and controls with SS, SC, CC, and AC are excluded. 
TABLE III

DISTRIBUTION OF IOO PATIENTS WITH BURKITT'S TUMOUR BY ABO BLOOD GROUPS COMPARED WITH EXPECTED DISTRIBUTION FROM CONTROLS (CHILDREN AND ADULTS

\begin{tabular}{l|c|c|c}
\hline \multirow{2}{*}{ Blood Group } & $\begin{array}{c}\text { Percentage of } \\
\text { Patients }\end{array}$ & \multicolumn{2}{|c|}{ Percentage of Controls* } \\
\cline { 3 - 4 } & $\begin{array}{c}\text { Yoruba Children } \\
\text { in Akufo Village } \\
(636)\end{array}$ & $\begin{array}{c}\text { Yoruba } \\
\text { Adults } \\
(26,027)\end{array}$ \\
\hline O & 53 & 52 & $51 \cdot 5$ \\
A & 23 & $20 \cdot 2$ & $21 \cdot 3$ \\
AB & 21 & $24 \cdot 0$ & $23 \cdot 3$ \\
AB & 3 & $3 \cdot 8$ & 3.9 \\
\hline
\end{tabular}

* Gilles (1963).

\section{Discussion}

It is increasingly useful to study the differences between persons suffering from some malignant neoplasm and a corresponding number of control persons, selected with a view to investigating single factors suspected of carcinogenicity. With no less than I child in every 25 over large parts of Africa having sickle-cell disease (Roberts, 1963) and a correspondingly higher incidence of sickle-cell trait, there is evidence of an increased frequency of the genes for abnormal haemoglobins in the population.

In so far as haemoglobin electrophoresis demonstrates the different varieties of haemoglobins present in the blood and these are genetically determined, it is permissible to employ this test for genotyping. In fact, haemoglobin electrophoretic pattern duplicates haemoglobin genotypes except in a few rare cases, thus making it a reliable and practical procedure. The present study is largely retrospective and has been possible only because suitable control data for haemoglobin genotypes are available, and because the majority of patients attending the hospital have had haemoglobin genotypes carried out. While this is not a usual routine laboratory test, it is done in large numbers at this hospital in the course of investigating various diseases, and it is most important to detect patients with abnormal haemoglobins.

The suitability of control groups cannot be overemphasized in a study of this kind as already pointed out by previous workers on blood groups. It is even more important in controls for haemoglobin genotypes, because knowledge of the distribution of genotypes reveals a significant difference in Yoruba children below and over the age of 5 (Table IV). The difference can probably be attributed to some advantages enjoyed by heterozygotes over normal homozygotes in early life.
Since malaria is thought to be lethal in children under the age of 5 and haemoglobin $S$ trait confe partial protection against the lethal effects off Plasmodium falciparum malaria, there is an increased incidence of the $S$ gene over the age of 5 . Therefori,; for this study, patients under the age of 5 had to ae excluded so that controls for genotypes would ideal. The control data for blood groups are also suitable, because there is no significant difference in the ABO distribution among adults and children (Table III). It is noteworthy that children of oth fy tribes in Nigeria develop Burkitt's tumour; bu they were excluded because of lack of suitabe control data. This partly accounts for the smait number of patients in the study.

It is worth noting that areas in Africa, where Burkitt's tumour is frequently encountered, have am increased frequency of genes for abnormal haemoglobins. The geographical distribution of the twos conditions has not yet been mapped, so that til significance of this association, if any, must rema speculative. However, the results from the presem study strongly suggest that children with $A \mathbb{A}$ genotype on haemoglobin electrophoresis are morg likely to develop Burkitt's tumour. It could b argued that this association is not real but a reflection of the pleiotropic effect of the genes or due to stratifications in the population. The observee difference, however, is significant and therefor cannot be overlooked. However, it has beef suggested that there is a relation between malaria and Burkitt's tumour (Edington, MacLean, an $\vec{E}$ Okubadejo, 1964; Dalldorf, Linsell, Barnhart, an Martyn, I964). This is probably not surprisin because the tumour occurs where there is arthropo transmission of viruses, and this would be in the areas where insect transmission of malaria prevalent. Since there is an increased representa tion of children without abnormal haemoglobins suffering from either malaria or Burkitt's tumoue one might speculate that these children are more

\section{TABLE IV}

DIFFERENCE IN HAEMOGLOBIN GENOTYPE DISTRD BUTION IN YORUBA CHILDREN LIVING NEAR IBADAN

\begin{tabular}{|c|c|c|}
\hline \multirow{2}{*}{ Genotype } & \multicolumn{2}{|c|}{ Akufo Village* } \\
\hline & $<5$ Years & $>5$ Years \\
\hline $\begin{array}{l}\text { AA } \\
\text { AS } \\
\text { SS, CC, SC, AC }\end{array}$ & $\begin{array}{l}72 \\
18 \\
10\end{array}$ & 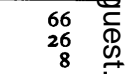 \\
\hline
\end{tabular}

$\chi^{2}=6.3860 ;$ d.f. $=2 ; 0.02<p<0.05$.

* Gilles (1963). 
liable to infections of which malaria is the commonest. It is conceivable that repeated malarial infections overstimulate the reticuloendothelial system, which then might form tumours more easily.

The tumour was observed in one child with haemoglobin SC and in another with sickle-cell anaemia. The tumour developed in $3 \%$ of children with AC genotype compared with $7.6 \%$ of the controls. There is a suspicion that there may be a deficiency of AC but the numbers are too few to draw any conclusions. The absence of the tumour in CC is of no significance because this genotype is rare. The greater likelihood of children with AA genotype developing the tumour may be further evidence of selective advantage of the $S$ gene compared to normal, thus influencing the genetic pattern of the population.

It is significant that there is no difference in the $\mathrm{ABO}$ blood group distribution between the patients and controls. Of possible relevance is the fact that haemoglobin constitution is genetically determined by pairs of allelic genes independent of those for the $\mathrm{ABO}$ groups. It is appreciated that these results are based on data from a small number of cases typical of Burkitt's tumour in a homogeneous community, and it is evident that more epidemiological studies of this kind are necessary to confirm the present observation.

\section{Summary}

The present study inquires into the possible relation between haemoglobin genotype or blood groups and Burkitt's tumour. In a series of 100 Yoruba children over the age of 5 with clinicopathological evidence of malignant lymphoma, there is evidence that children with AA genotype on haemoglobin electrophoresis are more susceptible to develop the tumour. There is no significant difference between the blood group distribution of patients and controls. The importance of suitable controls is discussed. Attention is drawn to haemoglobin genotype as a genetic factor which mav be involved in carcinogenesis.

I wish to thank Professors G. M. Edington, R. J. V. Pulvertaft, and A. O. Lucas for their help and advice in preparing this paper. I am grateful to the technical staff of the Haematology Department for the blood grouping and haemoglobin electrophoresis. I am most grateful to Mrs. Margaret Hendrickse of the Ibadan Cancer Registry for her valuable assistance.

\section{REFERENCES}

Aird, I., Bentall, H. H., Mehigan, J. A., and Roberts, J. A. F. (1954). The blood groups in relation to peptic ulceration and carcinoma of colon, rectum, breast, and bronchus. An association between the ABO groups and peptic ulceration. Brit. med. F., 2, 315.

-, Lee, D. R., and Roberts, J. A. F. (1960). ABO blood groups and cancer of oesophagus, cancer of pancreas, and pituitary adenoma. ibid., $1,1163$.

Beasley, W. H. (1960). Blood groups of gastric ulcer and carcinoma. ibid., $1,1167$.

Burkitt, D. (1958). A sarcoma involving the jaws in African children. Brit. F. Surg., 46, 218.

Dalldorf, G., Linsell, C. A., Barnhart, F. E., and Martyn, R. (1964). An epidemiologic approach to the lymphomas of African children and Burkitt's sarcoma of the jaws. Perspect. Biol. Med., 7 435.

Edington, G. M., MacLean, C. M. U., and Okubadejo, O. A. (1964). IOI necropsies on tumours of the reticulo-endothelial system in Ibadan. In The Lymphoreticular Tumours in Africa, a Symposium, ed. F. C. Roulet, p. 250. Karger, Basle and New York.

Gilles, H. M. J. (1963). Akufo-An Environmental Study of a Nigerian Village Community. Ibadan University Press, Ibadan.

Hembold, W. (I959). Über den Zusammenhang zwischen ABOBlutgruppen und weiblichem Genitalcarcinom. Bibl. haemat. (Basel), 10, 176.

Roberts, J. A. F. (1963). An Introduction to Medical Genetics, 3rd ed. Oxford University Press, London.

Worlledge, S. M. (1959). Annual Report, Department of Pathology, University of Ibadan, Nigeria. 